Варцаба B.I., Мостіпака O.B.

\title{
КОНСТРУЮВАННЯ СИНЕРГЕТИЧНИХ ЕФЕКТІВ В НАЦІОНАЛЬНІЙ ЕКОНОМЩЦ УКРАЇНИ
}

\begin{abstract}
В статті обгрунтовуються умови досягнення синергетичних ефектів в соиіально-економічній системі Украӥни; визначаються потениійні синергетичні ефекти, що створюватимуться у реальній економіці через зміну взаємозв'язків із національними грошово-фінансовими інструментами, які потенційно впливають на досягнення синергетичних ефектів в складі як факторів відтворення національного виробництва, так і інтелекту, який управляє комбінуванням иих факторів. Результати дослідження можуть бути використані при реформуванні соціально-економічної системи України та здійсненні ефективного синергетичного управління сочіально-економічною системою Украӥни в глобальних координатах розвитку.
\end{abstract}

Ключові слова: Синергетичний ефект, емерджентність, адитивність, синергія, дисинергія, моделювання та конструювання синергетичних ефектів.

Постановка проблеми. В умовах ентропійного глобального ринку необхідно розробити теоретико-методологічний фундамент для переходу до нової моделі розвитку соціальноекономічної системи в Україні, яка визначатиметься як ієрархічно-мережева ресурсозберігаюча реальна економіка 3 духовною домінантою розвитку, заснованою на знаннях, синергійноноваційних методах i технологіях транснаукового управління («суб'єкт» $\leftrightarrow$ «суб'єкт» управління), що включають інформаційні blockchain-технології, методи форсайт-технологій. В основі цього повинна бути покладена транснаукова (інтеграція знань 3 різних предметних областей) інформаційносинергетично-інституціональна парадигма моделі соціально-економічної системи в просторово-часових координатах розвитку та отримання інтегрально-синергійних ефектів. Враховуючи ситуацію, що склалась, в умовах функціонування моделі економіки «невидимої руки вільного ринку», Україна змушена буде переглянути існуючу модель економіки i скоригувати ii відповідно до усвідомлених національних інтересів.

Виникає нагальна необхідність розробляти (конструювати) таку стратегію розвитку соціально-економічної системи національної економіки, що орієнтована на отримання синергетичних ефектів, i, як наслідок, приросту валового внутрішнього продукту (ВВП). Під

(C) Варцаба Віра Іванівна, д.е.н., доц. завідувач кафедри фінансів і банківської справи Ужгородського національного університету, м. Ужгород, тел.: +380505026505, e-mail: vira.vartsaba@uzhnu.edu.ua Мостіпака Олена Василівна, здобувач наукового ступеня к.е.н., директор Компанії «Юрконсалтінг», м. Тернопіль, тел.: +380968914639, e-mail: mostipaka_olena@ukr.net синергетичним ефектом - (від грец. synergos спільно діючий, сприяння, співробітництво, співучасть) маємо на увазі зростання ефективності функціонування суспільноекономічної системи в результаті інтеграції, злиття окремих систем, підсистем, елементів в єдину систему - за рахунок системного ефекту (емерджентності).

Як відомо, синергетичний ефект $\epsilon$ універсальною категорією, один із аспектів якої полягає в перевищенні результатів колективної дії елементів економічної системи над сумою їх індивідуальних дій, приводить до зміни якості соціально-економічної системи, траєкторії іiі розвитку.

На нашу думку у більшості випадків суспільство просто не усвідомлює, до якої міри деякі ресурси - інтелект, знання, інформація, гроші як штучна інформація (ресурс, який $€$ найдешевший при емісії i ïx повинно бути достатньо для функціонування національної економіки) можуть бути надпродуктивними в просторово-часових координатах розвитку.

Аналіз останніх досліджень та публікацій. Питання синергізму досліджують українські та зарубіжні науковці, зокрема Д. Аакер, Д. Джонсон, Р. Уіттінгтон, А. Муратов, I. Поварич, А. Асаул, Н. Коултер, Х. Ітамі, М. Кітінг та ін. Функціонування грошей в соціально-економічній системі досліджено на основі праць Т. Ковальчука, А. Гриценка, В. Юровицького, В. Кроливецької, М. Гаркуші. Однак, невисвітленою залишається проблема конструювання синергетичних ефектів в національній економіці України, де чинником синергетичних ефектів $є$ гроші як підсистема складної синергетичної системи, на що звертають увагу автори даного дослідження. 
Формулювання цілей статті. Мета дослідження - обгрунтувати умови досягнення синергетичних ефектів в соціально-економічній системі України; описати синергетичні ефекти, що створюватимуться у реальній економіці через зміну взаємозв'язків із національними грошовофінансовими інструментами, які потенційно впливають на досягнення синергетичних ефектів в складі як факторів відтворення національного виробництва, так i інтелекту, який управляє комбінуванням цих факторів в просторовочасових координатах розвитку.

Опис основного матеріалу дослідження. Дослідження умов досягнення синергетичних ефектів в соціально-економічній системі - це важливий етап нашого дослідження. Науковий пошук спрямований на розуміння виникнення синергетичних ефектів у соціально-економічній системі. Синергетичний ефект можна пояснити постулатом Аристотеля: «Ціле - більше суми його частин» [1, с. 102-103]. На думку сучасних фахівців в області стратегічного управління Девіда А. Аакера [2, с. 209-210], Джеррі Джонсона [3, с. 358-359] сутність «синергії» полягає саме в тому, що ціле завжди є більшим від простої суми суми своїх частин.

В процесі інтегральної взаємодії структурних елементів відкритої нелінійної суспільноекономічної системи з'являється інтегральна синергійна властивість, виникає синергійний ефект, яким не володіла сукупність елементів до їх об'єднання в цілісну систему. Алгоритм наступний: цільовий, оптимальний, синергійноуправлінський вибір в сьогоденні здатний коректуючи програмувати майбутнє, досягаючи в цілому організованості, впорядкованості i синергізму (синергетичних ефектів) системи. В загальному синергетичний ефект утворюється в керуючій i керованій системах через інформаційну систему.

Автори роботи [4, с. 273] вважають, що ключ до уточнення понять «синергізм» i «емерджентність» дає визначення синергетики, а природа відмінностей - в переважному впливі факторів: внутрішні (ендогенні) формують синергізм, а зовнішні (екзогенні) фактори емерджентність. Синергізм властивий системі або організації природним чином і $є$ результатом єдності та цілісності іiі елементів, результатом самоорганізації. Саме синергізм характеризує організацію, а його прояв відрізняє фактичну, дійсну організацію від формальної. В системі управління синергізм проявляється в керованому суб'єкті.

Емерджентність, за визначенням дослідників [5, c. 264], є наслідком прояву як мінімум трьох чинників: різкого нелінійного посилення раніше малопомітної властивості; непередбачуваною біфуркацією будь-якої системи, підсистеми; рекомбінації зв'язків між елементами. Ефект синергії - складова частина емерджентності. Емерджентність здебільшого відноситься до явищ (організацій, об'єднань, союзів тощо), а синергія - до процесів, що відбуваються в підсистемах, елементах організацій.

Прогнозування,

моделювання

та

конструювання синергетичних ефектів $є$ одними 3 найважливіших задач в управлінні розвитком соціально-економічної системи. При цьому проблемою $\epsilon$ визначення основних сфер виникнення синергії. Синергетичний ефект має місце, коли система, утворена в результаті інтеграції систем (підсистем), генерує якісно нові властивості, якими не володіли системи (підсистеми) до їх об'єднання. Утворена система генерує сукупний ефект, який перевищує суму ефектів, які були характерні для систем (підсистем) до їх об'єднання. Таким чином, синергетичний ефект $\epsilon$ наслідком прояву властивості емерджентності або цілісності системи, який проявляється в системі шляхом виникнення у неї нових інтегрованих якостей, не

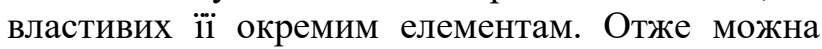
отримати нову якість, не вводячи в систему нових елементів, але організовуючи нові зв'язки.

Соціально-економічна система знаходиться між двома крайніми станами абсолютної цілісності та адитивності (незалежності). Оскільки соціально-економічні системи не адитивні для них завжди характерний певний рівень синергії. А отже для прояву синергетичних ефектів необхідно дотримуватися принципів неадитивності і комплементарності ресурсів, а також компетенцій нової системи. Синергетичний економічний ефект може утворюватися в соціально-економічній системі через комбінування в ході їх взаємодії підсистем, інститутів, елементів; праці, в т. ч. інтелектуальної, основних і оборотних фондів, природних ресурсів, грошей та порядку фінансування, організаційно-управлінських дій, на всіх рівнях економічної системи (нано-, мікро-, мезо-, макро-) і в процесі міжрівневих взаємодій. Властивість адитивності зазвичай характерна для якісно однорідних матеріальних ресурсів. При їх підсумовуванні має місце адитивність. Але і така система може генерувати синергетичні ефекти, які проявляються в можливій неадитивності витрат і доходів нової системи. Національна економіка може отримувати синергетичні ефекти, що виражаються в збереженні та відновленні природних ресурсів; економії матеріальних ресурсів; підвищенні ефективності та стійкості 
виробництва в результаті системного управління процесом впровадження інноваційних ресурсозберігаючих технологій те технологічних укладів. Однак утворення синергетичних ефектів в суспільно-економічних системах може мати як позитивні, так і негативні синергетичні ефекти (дисинергія).

Управлінські функції можуть і повинні бути використаними для створення умов виникнення й ефективного використання ефектів синергії у процесах господарської діяльності не в межах окремих суб'єктів господарювання, а для інтеграції різних суб'єктів господарювання в межах складних, ієрархічно-мережевих соціально-економічних систем. Якщо ж цього не відбувається, то система починає працювати проти себе, втрачаючи ресурси і результати, що у роботі [6, с. 12] інтерпретовано як результат нарощування в ній протилежності синергізму дисергізму.

Норман Артур Колтер (1920-2008 рр.) в 1976 р. у роботі [6, с. 10-12] пояснював синергізм людського розуму як результат спільної роботи великого розмаїття функцій, які становлять розум, зі створення нового цілого, яке є більшим ніж сума його частин. Він доводив, що кожна людина є не тільки індивідуальним інтелектом, а також членом певних етнічних груп та суспільства в цілому. При цьому індивідуальний інтелект може проявляти синергетичний режим діяльності. Н. Котлер вперше сформулював такі поняття як «індивідуальна», «групова» i «соціальна» синергетика, основою яких $є$ синергетична взаємодія, коли дії людини направлені на досягнення як особистих цілей, так i суспільної мети. Розкриваючи важливість синергетики в сфері науки у зв'язку iз поглибленням спеціалізації та виникненням труднощів взаємодії між різними предметними областями, Н. Котлер відмітив необхідність в фахівцях міждисциплінарного - людяхгенералістах, що здатні вирішувати проблеми шляхом інтеграції знань 3 різних предметних областей.

Людина $\epsilon$ джерелом творення, розвитку, флуктуацій та біфуркацій в соціальноекономічній системі. X. Ітамі у роботі «Невидимі активи» [7, с. 59-85] справжнім джерелом синергізму визнає тільки нематеріальні активи, під якими розуміються ресурси у вигляді знання, володіння технологіями. Цей же дослідник виділяє так званий «комплементарний ефект» (від лат. complementum - доповнення), суть якого полягає в тому, щоб сприяти співіснуванню двох незв'язаних елементів стратегії, зазвичай за рахунок використання одного i того ж матеріального або фінансового активу.
Відомий український вчений, д.е.н., професор, письменник, есеїст, публіцист Ю. М. Канигін в колективному монографічному дослідженні «Україна: інтелект нації на межі століть» [8, с. 37] пропонує науковий термін «сінтелектика» (як наука про функціонування колективного інтелекту, який створює синергетичний та сінтелектуальний ефекти) для інтеграції творчих елементів нелінійної суспільної системи, наділеної інтелектом (когнітивним рівнем). Сінтелектика, на думку Ю. Канигіна, будучи концептуальним доповненням синергетики, розглядає процеси і механізми інтелектуальної взаємодії 3 досягненням сінтелектуального ефекту iз наступним переходом його у інтегральний синергетичний ефект.

Розрізняють два види синергії: синергія розширення i синергія пов'язаності. Синергія розширення проявляється як результат набуття кожною із інтегрованих соціально-економічних систем можливості використовувати ресурси, наявні в іншої економічної системи. Синергія пов'язаності включає в себе тільки синергію, що виявляється в разі, якщо у об'єднаних економічних систем, в яких у кожної окремо недостатньо ресурсів, з'являється якісно новий ресурс. До таких ресурсів відносяться: інтелектуальні, інформаційно-знаннєві, матеріальні, енергетичні тощо.

Синергетичний ефект створюється безпосередньо в сфері управління та виробництва, проте це створення здійснюється на базі суспільного поділу і кооперації праці. Виникає об'єктивна необхідність прогнозування, моделювання, планування процесів кооперації праці в ході реального відтворювального процесу, в якому створюється синергетичний ефект. В національній суспільно-економічній системі повинна бути оптимізована величина i структура грошової маси, що в умовах функціонування моделі економіки «грабуючої руки вільного ринку» практично неможливо. Особливо при ऑii значному стисненні щодо оптимуму i деформації у вигляді концентрації величезної кількості грошей в фінансовій, банківській, спекулятивно-посередницькій сферах.

Найбільші можливості підвищення ефективності суспільного відтворювального процесу на всіх його рівнях містяться в раціональній трансформації грошовофінансового механізму економіки України в напрямку пii переорієнтації на максимізацію синергетичного ефекту, що досягається в першу чергу на базі інтелекту, інновацій, заснованих на науково-технічному прогресі (НТП) 6-7-го технологічних укладів. Позитивний 
синергетичний ефект створюється у реальній економіці через взаємозв'язок із національними грошово-фінансовими інструментами (пряма емісія грошей під інноваційні проекти), які потенційно впливають на досягнення синергетичного ефекту в складі як факторів відтворення національного виробництва, так i інтелектуального активного начала, яке управляє комбінуванням цих факторів. В умовах ентропійного нерегульованого ринку кредитногрошово-фінансові відносини не здатні забезпечити в системі національної реальної соціальної ресурсозберігаючої економіки позитивний синергетичний ефект, що базується на духовному, інтелектуальному й технологічному розвитку. $\mathrm{Ha}$ це здатний комплекс національних грошово-фінансових відносин, орієнтований на досягнення позитивного синергетичного ефекту із врахуванням параметрів інтелектуального, виробничого, соціального та екологічного порядку в просторово-часових координатах розвитку України. У зв'язку з цим вплив прямої емісії грошей на відтворювальний процес у всіх галузях національної економіки 3 метою досягнення синергетичного ефекту набуває особливої актуальності.

В Україні періоду ліберальних ентропійних ринкових «реформ» за порадами Міжнародного валютного фонду (МВФ), Світового банку (СБ) величина і структура грошової маси були не оптимальними, оскільки величина грошової маси виявилася стисненою по відношенню до ВВП (коефіцієнт монетизації (відношення М3 до ВВП) на 01.01.2016 становив $51 \%$ [9] (норматив $80 \%$ ВВП), що майже утричі нижче ніж у Голландії, Італії, Іспанії, Китаї, Німеччині, Франції, Японії та інших країн [10]. Таким чином, оптимізація величини i структури грошової маси шляхом прямої емісії національних грошей Національним банком України (НБУ) під інноваційно-інвестиційні проекти $\epsilon$ найважливішою передумовою формування i функціонування синергетично орієнтованої моделі національної економіки. В цьому контексті, необхідні інституційні зміни щодо функціонування НБУ, не як «філії» МВФ, а як центрального банку держави, який виконує одну із основних функцій: сприяє дотриманню стійких темпів економічного зростання та підтримує економічну політику Кабінету Міністрів України. Його необхідно підпорядкувати Верховній Раді України та КМУ 3 метою спільних дій щодо розбудови нової моделі національної економіки.

Вітчизняний дослідник Гриценко А. А. у роботі [11, с. 43] констатує, якщо $є$ матеріальні та трудові ресурси для розвитку виробництва, то ніяких зовнішніх запозичень не потрібно. С НБУ, в обов'язок якого входить забезпечення національної економіки грошима у кількості, необхідній для товарообороту, а іноземна валюта потрібна тільки для придбання на світових ринках лише тих необхідних товарів, що не можуть бути вироблені в Україні.

В соціально-економічній системі України структура грошової маси не оптимальна та спостерігається в ії непомірній концентрації в банківсько-фінансовій та спекулятивнопосередницькій сферах; валютний курс долара США до гривні в рази вище паритету купівельної спроможності двох валют, що перевищує допустимі межі відхилення валютного курсу; значна частина капіталу протягом 26 років незалежності безперервно переводиться в офшорні юрисдикції; суттєва частина грошових коштів держави перебуває в золотовалютних резервах і стабілізаційному фонді замість того, щоб вкладати ці гроші в розвиток національної економіки, в тому числі в сферу освіти, науки, новітні технології, охорону здоров'я, виробничу інфраструктуру, сільське господарство; надмірна частина грошової маси обслуговує престижно-розкішне споживання вузького соціального прошарку в той час, коли в Україні не вистачає грошей для забезпечення платоспроможного попиту на споживчому ринку, що гальмує розвиток реальної економіки; в структурі грошової маси занижена частка грошей, що вкладаються у виробничу сферу у довгостроковому періоді; грошово-фінансові потоки орієнтовані на спекулятивнопосередницькі операції, які виявляються в рази вигіднішими, порівняно 3 інвестиціями в реальний сектор економіки. У зв'язку 3 цим виникає необхідність переорієнтації фінансовогрошової підсистеми соціально-економічної системи України на розвиток реальної економіки та соціальної сфери на інтелектуально-знаннєвій основі 6-7 технологічних укладів 3 метою отримання синергетичних ефектів та досягнення рівня розвитку країн G20.

Інституціоналізовані алгоритми функціонування грошей залишаються прихованими, абстрактними, i зовні проявляються через функції грошей, які реалізуються і визначають роль грошей в національній економіці. Такий підхід $\epsilon$ важливим для розуміння сутності грошей та механізму управління національною економікою, оскільки саме через функції грошей реалізуються в національному господарстві суспільно-економічні відносини, що формують економічну категорію «гроші». 
В цьому контексті необхідно розрізняти роль грошей від їх функцій. Роль і призначення грошей визначаються їх використанням у національній економіці на всіх етапах процесу відтворення - виробництві, розподілі, обміні та споживанні. Функції ж грошей визначаються їх використанням тільки в сфері обігу (обміну) на ринку як внутрішньому, так і світовому. Тому необхідно розмежовувати категорії «функції грошей» і «роль грошей». В своєму дослідженні ми розглядаємо гроші як елемент системи, як одну із підсистем складної синергетичної соціально-економічної системи, де в результаті взаємодії з іншими підсистемами, інститутами, елементами утворюються синергетичні ефекти, які Гриценко А. А. визначає похідними функціями грошей, а багато вчених взагалі описують інші, так звані, «нові функції грошей», які з'являються в конкретній соціальноекономічній системі. Хочемо підкреслити, що гроші - це всього лише річ, інструмент, а 3 позицій інформаційно-знаннєвого суспільства штучна інформація, які функціонують за чітко визначеними, встановленими інституціоналізованими алгоритмами, тому питання треба ставити не про функції грошей, адже гроші самі по собі нічого не роблять, а про механізми та алгоритми функціонування грошей в тій чи іншій моделі економіки. I саме завдяки інституціоналізованим суспільно-необхідним алгоритмам функціонування грошей у національній економічній системі можна досягнути утворення синергетичних ефектів в суспільно-економічній системі в просторовочасових координатах розвитку.

Гроші $\epsilon$ універсальним економічним інструментом, який за допомогою певної системи інститутів може використовуватися для вирішення проблем соціально-економічної системи. Грошово-кредитна політика повинна враховувати ці обставини, мати в своєму арсеналі відповідні теоретичні концепції $\mathrm{i}$ практично їх втілювати в життя [12, с. 35].

Інформація природна i штучна здійснює інтерфейс (зв'язок) в суспільстві. Гроші як штучна інформація, що формується в головах людей, виступають в якості інформаційновимірювальної інституції та в соціальноекономічній системі представляють вимір i число.

До прикладу, Юровицький В. М. визначає такі функції грошей, як [13]: регулятор виробництва; регулятор споживання; вимірник суспільної корисності людини; стимулятор науково-технічного прогресу; екологічна функція; державна функція; функція грошей в міжнародному перерозподілі багатства; «кримінальна функція»; військова функція; миротворча функція грошей.

Автори даного дослідження називають надані (привнесені ззовні) функції синергетичними ефектами в суспільно-економічній системі, які утворюються від алгоритмів функціонування грошей та реальної економіки як елементів та підсистем однієї системи національної економіки.

Прикладом негативного синергетичного ефекту в умовах глобалізаційних перетворень, який утворюється через алгоритми функціонування інституціоналізованих сучасних кредитних грошей, $є$ за визначенням В. Кролівецької [14, с. 13-14] гроші як «фінансова зброя». У ролі «фінансової зброї» гроші можуть використовуватися для ослаблення економіки іноземної держави 3 метою економічного i політичного підпорядкування через світову кредитно-грошову фінансову систему. На даний час основними грошовофінансовими інструментами політичного впливу економічно сильних країн відносно країн що розвиваються для досягнення своїх політичних й економічних цілей $\epsilon$ : втягування в боргову залежність, насадження фінансових пірамід, пропаганда переваг економіки «вільного ринку» 3 iii «невидимою рукою», використання зарубіжних валют в порівнянні з національною, а також фінансування заходів 3 встановлення контролю над інститутами державної влади в інших країнах або демонтаж останніх, наприклад шляхом керованого хаосу, в результаті яких слабшають національні системи безпеки країн, інститути державної влади, виникають кризи фінансово-банківських систем і грошового обігу, соціальні кризи тощо. Щодо економічного i політичного впливу 3 боку інших країн не $\epsilon$ винятком і Україна, яку в 90-ті роки ХХ ст. МВФ втягував у боргову залежність, надаючи кредити в обмін на умови програм структурних реформ економіки «вільного ринку» 3 іï «невидимою грабуючою рукою», насаджуючи в грошовому обігу долар США, послаблюючи тим самим позиції національної валюти, втягуючи у фінансові піраміди, засновані на деривативах, які в 2007-2008 рр. стали генератором світової фінансово-економічної кризи, що є очевидним прикладом дисинергії на мега-макро рівнях.

М. С. Гаркуша в своїй роботі [15] ще розглядає таку функцію грошей у віртуальній економіці як спекулятивну. Автор роботи пише, що парадокс сучасної стадії розвитку грошей в тому, що вони самі, являючись, продуктом i механізмом економічного розвитку, відокремлюються від реальної економіки. Ріст грошового багатства тепер зовсім не означає 
розвиток реального виробництва i економічне зростання, а може бути навіть обернено пропорційний до нього: віртуальні фінансові маніпуляції, ігри на валютних курсах приносять небачені прибутки, але при цьому є негативними для економіки і загрозливими для благополуччя населення цілих регіонів світу. А. А. Гриценко в роботі [11, с. 43] наводить приклад. МВФ прийняв рішення перерахувати Україні 300 млрд дол. Що реально відбулось? Із записів на рахунках МВФ гроші перемістилися до записів на рахунках НБУ або уряду України. Ніякі реальні цінності нікуди не рухалися. Чи стала Україна на 300 млрд дол. багатшою? Велике запитання. А чи стала вона біднішою? Немає сумніву. Адже борг зріс у розрахунку на кожного громадянина нашої держави більш як на 7 тис. дол. I його треба буде віддавати реальною вартістю. На думку авторів даного дослідження це $є$ також приклади дисинергії. Грунтуючись на попередніх дослідженнях, необхідно відмітити, що діюча модель національної економіки «грабуючої руки вільного ринку» в Україні також є дисинергійною.

Виходячи iз викладеного, необхідно відмітити, що національні гроші як інструмент (інститут) функціонують за відповідними алгоритмами, законами в залежності від моделі розвитку соціально-економічної системи. Унікальність внутрішніх інституційних і структурних умов відтворення може бути забезпечена лише суверенітетом як осмисленим алгоритмом використання інтегрованих національних ресурсів в просторово-часових координатах розвитку України. Суб'єкти грошово-кредитної політики загальнодержавного рівня України мають бути суверенними у визначенні цілей i критеріїв здійснення монетарної політики, у системному змістовному взаємозв'язку і взаємозалежності 3 реальною економікою, розвивати осмислені інститути суверенітету. Такий варіант розвитку вбачається авторами лише через зміну механізму емісії сучасних грошей.

Ефект синергізму можна спостерігати також при ситуації, що характерна для теорії рівноваги Неша [16] (Джон Форбс Неш молодший (19282015), американський математик у галузі теорії ігор та диференціальної геометрії, Лауреат Нобелівської премії 3 економіки 1994 р., Абелівської премії 2015 р.), коли обидва контрагенти виграють («виграв ↔ виграв» теорія ігор), за якої успіх одного учасника досягається не за рахунок іншого та не виключає такого ж успіху для іншого, а завдяки прийняттю учасниками узгоджених рішень.
На думку проф. М. Кітінга загальні інтереси суспільно-економічної системи будуть реалізованими тільки тоді, якщо вони будуть інституціоналізовані [17]. Інституціоналізація загальних інтересів на макрорівні може бути реалізованою в межах концептуальної схеми гармонізованого управління множиною підсистем соціально-економічної системи, в якій комплексне використання феноменів сінтелектики («колективний розум» $\leftrightarrow$ «спільне мислення») i синергії (спільна дія) стає підгрунтям досягнення цією системою стану синархії (спільного управління) 3 отриманням відповідного місця в ієрархії удосконалення i гармонізації стосунків індивідуумів, спрямованих на досягнення добробуту в суспільно-економічній системі $[18$, с. 251$]$.

У соціально-економічній системі при створенні відповідних умов можуть формуватися різні синергетичні ефекти, які можна об'єднати в такі групи: інтелектуальний синергізм синергізм управління, фінансовий синергізм, операційний синергізм, синергізм «масштабу», інвестиційний синергізм, торговий синергізм та інші. Управлінський синергізм визначає загальний позитивний ефект в керуючій системі (поєднання природнього індивідуального i колективного інтелекту та штучного інтелекту). Операційний синергізм виникає, коли більш ефективно використовуються виробничий потенціал - ресурси. Синергізм людини природний та штучний інтелект інформаційно знаннєвих технологій - комбінація людських знань та вмінь в системі інтелектуальних трансформерних технологій.

Висновки i перспективи подальших досліджень. Синергетичні ефекти утворюються за наступних умов: у системі з'являється новий елемент, підсистема (синергія розширення); i/aбо змінюються взаємозв'язки між підсистемами, елементами, які вже існують у системі (синергія пов'язаності). Оскільки соціально-економічна система неадитивна, то можна стверджувати, що елементи, підсистеми володіють необхідною зв'язаністю та цілісністю. В нашому випадку має місце розгляд наступних підсистем: підсистема реальної економіки (виробництво, розподіл, обмін, споживання); фінансово-грошова підсистема (механізм емісії грошей, в т. ч. віртуальних - ЕГ, криптовалюти, алгоритми функціонування грошей, зміна кредитної сутності грошей); інформаційно-технологічна підсистема (розвиток технологій); управлінська підсистема - природний та штучний інтелект (трансформерні інформаційні технології, blockchain-платформа тощо). Найбільший потенціал синергізму криється саме в 
управлінській підсистемі та в суспільній підсистемі - (людина) і суспільний інтелект сінтелектика. В результаті зміни взаємозв'язків між вказаними підсистемами можна отримати синергетичні ефекти.

Основна зміна взаємозв'язків та взаємозалежностей, яку автори підкреслюють у даному дослідженні - це зміна взаємозв'язків між реальною економікою та грошовою підсистемами шляхом зміни кредитної сутності грошей через канал прямої емісії на основі blockchain-платформи віртуальних грошей - ЕГ, національної криптовалюти, яку необхідно розробляти (в Україні $є$ необхідний інтелект і знання). Тут криється, на нашу думку, величезний потенціал відродження та розвитку соціально-економічної системи в цілому i повернення Україні суб'єктності в глобальному суспільно-економічному просторі, що і стане тематикою подальших досліджень.

\section{ПЕРЕЛІК ВИКОРИСТАНИХ ДЖЕРЕЛ}

1. Аристотель. Метафизика. Соч. в 4-х т. [Текст] / Аристотель. - М.: Мысль, 1976. - Т.1. - 550 с.

2. Аакер Д. А. Бизнес-стратегия: от изучения рыночной среды до выработки беспроигрышных решений / Д. А. Аакер [пер. с англ.]; под ред. С.Г. Божук. - М.: Эксмо, 2007. - 464 с.

3. Джонсон Д. Корпоративная стратегия: теория и практика / Джонсон Д., Шоулз К., Уиттингтон Р. [7-е издание]; пер. с англ. - М.: И. Д. Вильямс, 2007. - 800 с.

4. Муратов А. С. Синергизм и эмерджентность: генезис их гармонизации в экономике и управлении / А. С. Муратов, И. П. Поварич // Вестник КемГУ. - 2012. - № 1 (49). - С. 271-275.

5. Асаул А. Н. Самоорганизация, саморазвитие и саморегулирование субъектов предпринимательской деятельности в строительстве: монография / А. Н. Асаул, Н. Н. Загускин, Л. Ф. Манаков, Е. И. Рыбнов; под ред. А. Н. Асаула. - СПб.: АНО «ИПЭВ», 2013. - 320 с.

6. Coulter N. A. Human Synergetics / N. A. Coulter. - New York : Prentice-Hall, Inc., 1976. - 201 p.

7. Итами Х. Невидимые активы // Стратегический синергизм / Э. Кемпбелл, К. Саммерс Лачс. 2-е изд. СПб.: Питер, 2004. - С. 59-85.

8. Україна: Інтелект нації на межі століть: кол. монографія / [кер. автор. кол. В. К. Врублевський]. - К. : Інтелект, 2000. - 516 с.

9. Основні показники, що характеризують стан грошово-кредитного ринку (за оперативними даними) // Офіційний сайт НБУ [Електронний ресурс]. -2 Режим доступу https://bank.gov.ua/doccatalog/document?id=26252478.

10. Ковальчук Т. «Грабіж» у особливо великих розмірах [Електронний ресурс] / Т. Ковальчук. - 08.03.2015. Режим доступу - http://news.finance.ua/ua/news/ /345904.

11.Гриценко А. А. Логіко-історичні засади кардинальних економічних змін і переходу до реконструктивного розвитку / А. А. Гриценко // Економіка України. - 2017. - № 5-6. - С. 39-57.

12. Гриценко А. А. Гроші як інструмент економічного реформування / А. А. Гриценко // Філософія фінансової цивілізації: людина у світі грошей : зб. наук. пр. / відп. секретар 3. Е. Скринник. - К.: УБС НБУ, 2015. - С. 26-36.

13. Юровицкий В. М. Денежное обращение в эпоху перемен [Електронний ресурс]: науч.-практ. пособ. / В. М. Юровицкий. - ГроссМедиа:РОСБУХ, 2007.- Режим доступу: http://yur.ru/Denejnoe_Obrashenie.pdf.

14. Кроливецкая В. Э. Деньги и денежное предложение в условиях формирования новой модели развития российской экономики: автор. дис. на соиск. уч. ст. докт. экон. наук: спец. 08.00.10 «Финансы, денежное обращение и кредит» / В. Кроливецкая. - Санкт-Петербург, 2013. - 40 с.

15. Гаркуша М. С. Новые функции денег в виртуальной экономике [Електронний ресурс] / М. С. Гарькуша // Журнал Российского государственного педагогического университета им. А. И. Герцена. - 2009.- № 119.- С. 96101. - Режим доступу до журн.: ftp://lib.herzen.spb.ru/text/garkusha_119_96_101.pdf.

16. Олексюк О. С. Рівновага соціально-економічних систем в контексті економічної безпеки / О. С. Олексюк, О. В. Мостіпака // Інноваційна економіка. - 2012. - № 7. - С. 302-305.

17. Keating M. Governing cities and regions: territorial restructuring in a global age / M. Keating [Електронний pecypc] - $\quad$ Режим http://www.euskara.euskadi.eus/contenidos/informacion/7379/eu_2344/adjuntos/KEATINGScott.pdf.

18. Варцаба В. І. Синергетична парадигма гармонізованого управління людськими ресурсами соціальноекономічних систем / В. І. Варцаба // Проблеми економіки. - 2015. - № 2. - С. 247-252.

\section{REFERENCES}

1. Aristotel'. (1976). Metafizika. [Metaphysics] (Vols.1-4, T.1) - Moscow: Mysl' [in Russian].

2. Aaker, D.A. (2007). Biznes-strategiya: ot izucheniya rynochnoy sredy do vyrabotki besproigryshnykh resheniy [Business strategy: from the study of the market environment to the development of win-win solutions]. S.G. Bozhuk. (Ed.). Moscow: Eksmo [in Russian].

3. Dzhonson, D., Shoulz, K. \& Uittington, R. (2007). Korporativnaya strategiya: teoriya i praktika [Corporate strategy: theory and practice]. Moscow: I. D. Vil'yams [in Russian]. 
4. Muratov, A.S. \& Povarich, I.P. (2012). Sinergizm i emerdzhentnost': genezis ikh garmonizatsii v ekonomike i upravlenii [Synergism and emergence: the genesis of their harmonization in economics and management] Vestnik KemGU. - Bulletin of KemSU, 1(49), 271-275 [in Russian].

5. Asaul, A.N., Zaguskin, N.N., Manakov, L.F., Rybnov, Ye.I. (2013) pod red. A. N. Asaul. Samoorganizatsiya, samorazvitiye i samoregulirovaniye sub"yektov predprinimatel'skoy deyatel'nosti v stroitel'stve [Self-organization, selfdevelopment and self-regulation of subjects of entrepreneurial activity in construction]. A.N. Asaul. (Ed.). - St. Petersburg: ANO «IPEV» [in Russian].

6. Coulter N. A. Human Synergetics / N. A. Coulter. - New York : Prentice-Hall, Inc., 1976. - 201 p. [in English].

7. Itami, KH. (2004). Nevidimyye aktivy [Invisible assets]. Strategicheskiy sinergizm - Strategic synergies. E. Kempbell, K. Sammers Lachs (Eds.). St. Petersburg: Piter, 2004. [in Russian].

8. Vrublevs'kiy, V.K. \& et al (2000). Ukraïna: Íntelekt natsîi na mezhí stolít': kol. Monografíya. [Ukraine: The Intellect of the Nations on the Verge of Centuries]. - Kiev : Íntelekt. [in Ukrainian].

9. Osnovní pokazniki, shcho kharakterizuyut' stan groshovo-kreditnogo rinku (za operativnimi danimi) [The main indicators characterizing the state of the money market (according to operational data)] Ofítsíyniy sayt NBU. - The official website of the National Bank of Ukraine bank.gov.ua. Retrieved from: https://bank.gov.ua/doccatalog/document?id=26252478. [in Ukrainian].

10. Koval'chuk, T. (2015). «Grabízh» u osoblivo velikikh rozmírakh [Yelektronniy resurs. ["Robbery" in Extremely Large Sources] news.finance.ua Retrieved from: http://news.finance.ua/ua/news/ /345904. [in Ukrainian].

11. Gritsenko, A.A. (2017) Logíko-ístorichní zasadi kardinal'nikh yekonomíchnikh zmín í perekhodu do rekonstruktivnogo rozvitku [Logico-historical principles of fundamental economic changes and the transition to reconstructive development]. Ekonomika Ukrayiny.. - Economy of Ukraine, 5-6, 39-57. [in Ukrainian].

12. Gritsenko, A.A. (2015). Groshi yak instrument yekonomichnogo reformuvannya [Money as an instrument of economic reform]. Fílosofíya fínansovoï tsivílízatsií: lyudina u svítí groshey. Philosophy of financial civilization: a man in the world of money. Z.Ye. Skrinnik. (Ed.). Kiev: UBS NBU

13. Yurovitskiy, V.M. (2007). Denezhnoye obrashcheniye v epokhu peremen [Money circulation in the era of change]. GrossMedia: ROSBUKH. yur.ru Retrieved from: http://yur.ru/Denejnoe_Obrashenie.pdf.

14. Krolivetskaya, V.E. (2013) Den'gi i denezhnoye predlozheniye v usloviyakh formirovaniya novoy modeli razvitiya rossiyskoy ekonomiki. [Money and money supply in the conditions of formation of a new model of development of the Russian economy]. Extended abstract of Doctor's thesis. - Sankt-Peterburg, St. Petersburg. [in Russian].

15. Garkusha, M.S. (2009). Novyye funktsii deneg v virtual'noy ekonomike [New functions of money in a virtual economy] Zhurnal Rossiyskogo gosudarstvennogo pedagogicheskogo universiteta im. A.I. Gertsen. - ournal of the Russian State Pedagogical University. AI Herzen, 119, 96-101. lib.herzen.spb.ru Retrieved from: ftp://lib.herzen.spb.ru/text/garkusha_119_96_101.pdf. [in Russian].

16. Oleksyuk, O.S. \& Mostípaka O.V. (2012). Rívnovaga sotsíal'no-yekonomíchnikh sistem v kontekstí yekonomíchnoï bezpeki [Equilibrium of socio-economic systems in the context of economic security]. Ínnovatsiyna yekonomika. - Innovation economy. 7, 302-305. [in Ukrainian].

17. Kiting, M. (2015). Governing cities and regions: territorial restructuring in a global age www.euskara.euskadi.eus Retrieved from http://www.euskara.euskadi.eus/contenidos/informacion/7379/eu_2344/adjuntos/KEATINGScott.pdf. [in English].

18. Vartsaba, V.Í. (2015). Sinergetichna paradigma garmonízovanogo upravlínnya lyuds'kimi resursami sotsíal'noyekonomíchnikh sistem [Synergetic Paradigm of Harmonized Human Resources Management of Socioeconomic Systems]. Problemy ekonomiky. - Problems of Economics. 2, 247-252. [in Ukrainian].

Одержано 15.09.2017p. 